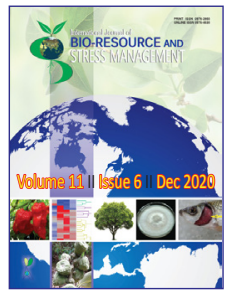

\title{
Ethephon Reduces Lodging and Enhances Seed Yield and Quality in Onion
}

\author{
V. R. Yalamalle*, T. Arunachalam, R. Kumari, D. M. Ithape, S. Ghosh and M. Singh \\ ICAR-Directorate of Onion and Garlic Research, Pune Maharashtra (410 505), India
}

\begin{tabular}{l}
\hline \hline Open Access \\
Corresponding Author \\
V. R. Yalamalle \\
e-mail: vishwanath_yal@yahoo.com \\
Citation: Yalamalle et al., 2020. Ethephon Reduces \\
Lodging and Enhances Seed Yield and Quality in \\
Onion. International Journal of Bio-resource and \\
Stress Management 2020,11(6), 601-606. HTTPS:// \\
DOI.ORG/10.23910/1.2020.2132a.
\end{tabular}

Copyright: $@ 2020$ Yalamalle et al. This is an open access article that permits unrestricted use, distribution and reproduction in any medium after the author(s) and source are credited.

Data Availability Statement: Legal restrictions are imposed on the public sharing of raw data. However, authors have full right to transfer or share the data in raw form upon request subject to either meeting the conditions of the original consents and the original research study. Further, access of data needs to meet whether the user complies with the ethical and legal obligations as data controllers to allow for secondary use of the data outside of the original study.

Conflict of interests: The authors have declared that no conflict of interest exists.

\begin{abstract}
Onion is an important vegetable crop grown in almost all parts of the World as a flavouring agent in food preparation. It is propagated by seeds and the seed crop is affected by several fungal, viral and bacterial diseases which cause lodging and reduces the seed yield and quality. Onion seed crop was sprayed with different concentration of ethephon $(0,100,200,400,600,800$ and 1000 ppm) for two duration at 45 or $45+60$ days after planting during (DAP) during 2018-19 and 2019-20 rabi seasons. The effect of ethephon on seed yield and seed quality was studied. In comparison to control ethephon application significantly reduced scape length and \% lodging by $38.73 \%$ and $42.52 \%$ respectively. There was $31.90 \%$ and $89 \%$ enhancement in scape diameter and yield respectively. Ethephon spray also enhanced seed quality, highest germination and seed vigour was recorded in plants sprayed with 600 ppm ethephon at 45 and 60 DAP which was $19 \%$ and $51.65 \%$ higher than control. Highest seedling dry weight was observed in plants sprayed with $100 \mathrm{ppm}$ ethephon at 45 DAP. Among the treatments, 100 and 200 ppm ethephon applied at 45 DAP had lower lodging and higher seed yield and seed quality. Hence spraying of onion seed crop with 100 ppm ethephon at 45 DAP is beneficial for getting higher seed yield and quality.
\end{abstract}

Keywords: Ethephon, onion seed, lodging, yield, germination, seed quality

\section{Introduction}

Onion (Allium cepa L.) is a major vegetable next only to tomato in terms of area and production. In India, it is grown in $1.32 \mathrm{~m}$ ha with the production of $22.07 \mathrm{mt}$ (Anonymous, 2018). The productivity of onion in India is $16.78 \mathrm{t} \mathrm{ha}^{-1}$, which is much lower than the productivity of the USA and the Republic of Korea. One of the major reasons for lower productivity in India is the limited availability of quality seed and poor seed replacement rate (Yalamalle, 2016). By improving the availability of quality seeds, the productivity of onion can be increased (Yalamalle and Tomar, 2019).

Onion is a biennial crop, during the first-year bulbs are produced and the harvested bulbs are planted in the second year to produce seeds. The crop stand and seed quality are affected by several fungal and bacterial diseases, which weakens the root system and cause lodging after scape (flower stalk) emergence (Abo-Elyousr, 2020). At seed filling stage incidence of Stemphylium bight (Stemphylium vesicarium), Botrytis umbel blight (Botrytis byssoidea and B. allii) and viruses- Irish yellow spot virus (IYSV) are seen on the scape, which girdles the scape, reducing the passage of photosynthates to the developing seeds (Mishra et al., 2014; Schwartz
Article History

RECEIVED in $15^{\text {th }}$ July 2020 RECEIVED in revised form $25^{\text {th }}$ November 2020 ACCEPTED in final form $14^{\text {th }}$ December 2020 
and Mohan, 2016). These weakened scapes are susceptible to lodging. Despite chemical treatments management of lodging is difficult, hence there is a need to strengthen the scapes by either reducing the scape height and or increasing the scape diameter (Kumar et al., 2016).

Ethylene is a gaseous multifunctional phytohormone which controls both growth and senescence of plants. Its action depends on its concentration, the timing of application, plant species and environmental condition (Van de Poel et al., 2015). Together with several hormones-gibberellic acid, jasmonates, salicylate, and abscisic acid, ethylene regulate most of the plant process from germination to senescence (Liu et al., 2017). In many plants species, the plant height is regulated by internodal differentiation and rapid internodal elongation. This growth response is governed by mainly two growth hormones ethylene and gibberellic acid (Saithong et al., 2015; Wang et al., 2017). Growth retardants like paclobutrazol have been reported to reduce the scape length and lodging (Ashrafuzzaman et al., 2009; Kumar et al., 2016). But the major disadvantage of paclobutrazol is it reduces the tillers and there was no significant enhancement in the seed yield (Ashrafuzzaman et al., 2009). Hence there is a need to find other chemicals which reduce the scape height and also enhance the seed yield. Ethephon [ETH (2-chloroethylphosphonic acid, an ethylene-releasing compound)] commercially available as Etrel ${ }^{\odot}$, it is known to reduce plant height in fruit trees, herbaceous annuals and field crops (Barker, 2016; Tidemann, 2020). Ethylene is reported to provide lodging resistance by promoting the outgrowth of young root primordia. Exogenous application of the ethylene precursor 1-aminocyclopropane-1carboxylic acid (ACC) promoted the emergence of nodal roots in maize and upregulated the expression of genes involved in cell wall biogenesis (Shi et al., 2019). Ethephon treatment is known to enhance drought and water logging tolerance, provide membrane stability and enhance antioxidant activity (Zhang et al., 2018; Shiono et al., 2019). There is limited information available on the use of ethephon in onion seed crop. Considering the above limitation and the lodging losses in onion seed crop the present study was conducted to know the effect of ethephon application in onion seed crop.

\section{Materials and Methods}

\subsection{Experimental details}

The field experiment was conducted at research farms of ICARDirectorate of Onion and Garlic Research ( $18^{\circ} 51^{\prime} \mathrm{N}, 73^{\circ} 53^{\prime} \mathrm{E}$ and at $596 \mathrm{~m}$ elevation). The region has a hot semi-arid climate (BSh), with an average annual rainfall of $722 \mathrm{~mm}$ during June and September, and July is the wettest month of the year. The experiment was laid out in randomized complete block design with three replications. Each treatment block measuring $10 \mathrm{X}$ $5 \mathrm{~m}^{2}$ was planted with 90 onion bulbs weighing $60 \pm 5 \mathrm{~g}$ each. To ease the scape emergence top $1 / 3^{\text {rd }}$ of the bulb was removed. The onion seed crop was sprayed with different concentration of ethephon (Ethrel ${ }^{\circledR}$, Ethephon 39 SL Bayer Crop Science,
India) at 45 days after planting (DAP) and 60 DAP (Table 1). The experiment was conducted during two consecutive seasons in 2018-19 and 2019-20 during rabi (winter) season. The planting was done on 22 November 2019 and 30 November 2020, during first and second season respectively. The onion seed bulbs were planted in ridges and furrow method at a spacing of $45 \times 30 \mathrm{~cm}^{2}$. Half dose of $\mathrm{N}$ and a full dose of $P$ and $K$ were given at the time of sowing. The plots were fertilized with 150 : 50: 50 (N: P: K) and 10 tonnes of FYM ha-1. The remaining half dose of the nitrogen was split into two equal doses and applied at 30 and 45 days after planting. Immediately after planting, plots were sprayed with $1.5 \mathrm{ml} \mathrm{l}^{-1}$ pre-emergent herbicide oxyfluorfen $23.5 \%$ EC, weeds at a later stage were managed by hand weeding. Plants were irrigated as per requirement. Earthing up was done 45 days after planting.

\begin{tabular}{ll}
\hline \multicolumn{2}{l}{ Table 1: Treatment details } \\
\hline $\mathrm{T}_{1}$ & $100 \mathrm{ppm}$ ethephon at 45 DAP \\
$\mathrm{T}_{2}$ & 200 ppm ethephon at 45 DAP \\
$\mathrm{T}_{3}$ & $400 \mathrm{ppm}$ ethephon at 45 DAP \\
$\mathrm{T}_{4}$ & $600 \mathrm{ppm}$ ethephon at 45 DAP \\
$\mathrm{T}_{5}$ & $800 \mathrm{ppm}$ ethephon at 45 DAP \\
$\mathrm{T}_{6}$ & $1000 \mathrm{ppm}$ ethephon at 45 DAP \\
$\mathrm{T}_{7}$ & $100 \mathrm{ppm}$ ethephon at 45 DAP and 60 DAP \\
$\mathrm{T}_{8}$ & $200 \mathrm{ppm}$ ethephon at 45 DAP and 60 DAP \\
$\mathrm{T}_{9}$ & $400 \mathrm{ppm}$ ethephon at 45 DAP and 60 DAP \\
$\mathrm{T}_{10}$ & $600 \mathrm{ppm}$ ethephon at 45 DAP and 60 DAP \\
$\mathrm{T}_{11}$ & $800 \mathrm{ppm}$ ethephon at 45 DAP and 60 DAP \\
$\mathrm{T}_{12}$ & $1000 \mathrm{ppm}$ ethephon at 45 DAP and 60 DAP \\
$\mathrm{T}_{13}$ & Control water spray \\
\hline
\end{tabular}

All the field observations were recorded on 10 plants in each replication and averaged. The observations- number of tillers plant $^{-1}$, scape length and scape diameter, were recorded at the $50 \%$ anthesis. The \% lodged scapes were calculated by counting the total number of un-lodged scapes after the seed filling stage and the \% was calculated based on the initial scapes number. Seed yield plant ${ }^{-1}$ was recorded on randomly selected 10 plants after maturity. The umbels were harvest when about $30 \%$ of the seeds in the umbel turned black. The harvested umbels were sundried, threshed manually.

\subsection{Seed quality assessment}

Seed quality evaluation was done as per ISTA guidelines (Anonymous, 2015). The germination \% was evaluated by the top of the paper method by placing 50 seeds in three replicates on a blotter paper. The seeds were kept in the BOD incubator set at $20 \pm 1^{\circ} \mathrm{C}$ for 12 days. The seedling length and seedling dry weight was calculated based on randomly selected ten normal seedlings on the $12^{\text {th }}$ day. The seedling vigour index 
was calculated as per Abdul-Baki and Anderson (1973). Vigour index = germination $\% \times$ seedling dry weight $(\mathrm{mg})$

\subsection{Statistical analysis}

The analysis of quantitative data generated was performed by using SAS software version 9.3. The data collected were subjected to two-way ANOVA and means were separated by the least significant difference test (at $p \leq 0.05$ ). Grouping letters on treatment means were assigned using Fishers' least significant difference. Means with at least one common letter were not statistically significant.

\section{Results and Discussion}

Lodging is one of the major problems faced by the onion seed producers. The crop stand in onion seed crop is affected by several biotic and abiotic factors. The bolting and scape emergence stage coincide with the heavy incidence of Stemphylium bight (Stemphylium vesicarium), Botrytis umbel blight (Botrytis byssoidea and B. allii) and viruses- Irish yellow spot virus (IYSV) which cause nectropic lesions on the scape and increases the susceptibility to lodging. Reduction in scape height has been related to higher mechanical stability. Onion seed crop was sprayed with different concentration of ethephon $100 \mathrm{ppm}$ to $1000 \mathrm{ppm}$ at 45 and 60 DAP to study its effect on the lodging.

\subsection{Number of tillers}

The application of ethephon did not affect the number of scapes plant ${ }^{-1}$ (Table 2). Previous studies in cereals report an increase in tillers with ethephon application (Praharaj et al., 2017; Tripathi et al., 2003; Addaheri and Abood, 2020). The differential response may be due to the difference in the nature of the crop, unlike cereals the growing tillers are enclosed deep within the bulb in the onion seed crop. Moreover, the first spray was initiated at 45 DAP, wherein the majority of the tillers had already emerged.

\subsection{Scape length}

The poled analysis of the data for scape length clearly indicate the significant (at $p \leq 0.05$ ) difference between the treatments (Table 2). Highest scape length $(51.09 \mathrm{~cm}$ ) was recorded in control and lowest scape length $(36.22 \mathrm{~cm})$ was recorded in treatment $T_{12}(1000 \mathrm{ppm}$ ethephon at 45 and $60 \mathrm{DAP})$, which was also at par with treatments $\mathrm{T}_{4}(600 \mathrm{ppm}$ ethephon at 45 DAP), $T_{5}(800 \mathrm{ppm}$ ethephon at $45 \mathrm{DAP})$ and $\mathrm{T}_{6}(1000 \mathrm{ppm}$ ethephon at 45 DAP). The scape bears flowers at the terminal part, which develops to form the seeds, the economical part of the crop. Long and slender scapes cannot bear the weight of the developing umbel and lodge. Lower scape height is beneficial for reducing the lodging and aid in mechanical harvesting (Kumar et al., 2016). The results are in agreement with the previous studies of Hayashi et al. (2001) and Tripathi et al. (2003).

\subsection{Scape diameter}

The poled analysis of the data for scape diameter clearly indicate the significant (at $p \leq 0.05$ ) difference between the treatments (Table 2). Highest scape diameter $(1.53 \mathrm{~cm})$ was recorded in treatment $T_{12}(1000 \mathrm{ppm}$ ethephon at 45 and 60 DAP) and lowest scape diameter which recorded in control, which was also at par with treatments $T_{1}(100 \mathrm{ppm}$ ethephon at 45 DAP). Ethephon is reported to increases the thickness of primary and secondary structures in stems (Mangieri et al., 2016). Exogenous application of the ethylene precursor 1-aminocyclopropane-1-carboxylic acid (ACC) upregulated expression of genes involved in cell wall biogenesis in maize (Shi et al., 2019). Increased stem diameter due to ethephon application has been reported previously by Li et al., 2019 and Zhang et al., 2019 there is little information on how ethephon regulates internode mechanical properties to improve maize stalk strength. Multiyear field experiments (2013-2017 in maize.

\subsection{Percentage lodged scapes}

Lodging resistance is closely associated with internodes length and stem diameter (Zhang et al., 2019) there is little information on how ethephon regulates internode mechanical properties to improve maize stalk strength. Multiyear field experiments (2013-2017. In the present study ethephon application significantly reduce the scape length and increased the scape diameter, which contributed to reduced lodging (Table 2). Though the higher concentration of ethephon (1000 ppm at 45 and 60 days) reported lower scape length and higher scape diameter, lower lodging was reported in $\mathrm{T}_{1}$ (100 ppm ethephon applied at 45 DAP), which was also at par with treatments $T_{2}$ (200 ppm ethephon at $\left.45 \mathrm{DAP}\right), \mathrm{T}_{4}(600$ ppm ethephon at $45 \mathrm{DAP}), \mathrm{T}_{7}$ (100 ppm ethephon at 45 and 60 DAP), $T_{9}\left(400\right.$ ppm ethephon at 45 and 60 DAP) and $T_{10}(600$ ppm ethephon at 45 and 60 DAP). Foliar spray of ethephon at $75 \mathrm{ppm}$ enhanced lignin in stems of barley thus providing mechanical strength and reducing the lodging (Ahmad et al., 2020). Plants sprayed with a higher concentration of ethephon had lodging similar to that of control indicting phytotoxic effect of ethephon at higher concentration. Monarda foliage sprayed with $1000 \mathrm{mg} \mathrm{l}^{-1}$ ethephon caused necrosis (Hayashi et al., 2001). Ethephon is known to induce senescence (Li et al., 2013), hence plant spayed with a higher concentration of ethephon senescence early and had high lodging.

\subsection{Umbel diameter}

The poled analysis of the data for umbel diameter clearly indicate the significant (at $p \leq 0.05)$ difference between the treatments (Table 2). Highest umbel diameter $(6.65 \mathrm{~cm})$ was recorded in treatment $T_{10}(600 \mathrm{ppm}$ ethephon at 45 and 60 DAP) which was at par with treatments $T_{4}(600 \mathrm{ppm}$ ethephon at $45 \mathrm{DAP}), \mathrm{T}_{5}$ (800 ppm ethephon at $\left.45 \mathrm{DAP}\right), \mathrm{T}_{10}(600 \mathrm{ppm}$ ethephon at 45 and $60 \mathrm{DAP}), \mathrm{T}_{11}$ (800 ppm ethephon at 45 and $60 \mathrm{DAP}), \mathrm{T}_{12}$ (1000 ppm ethephon at 45 and $60 \mathrm{DAP}$ ) and control. Lowest umbel diameter was recorded in $T_{1}(100$ ppm ethephon applied at $45 \mathrm{DAP})$, which was also at par with treatments $T_{2}$ (200 ppm ethephon at 45 DAP), $T_{3}$ (400 ppm 
Table 2: Effect of ethephon application on tillers, scape length, scape diameter, \% lodged scapes, umbel diameter and seed yield in onion seed crop

\begin{tabular}{|c|c|c|c|c|c|c|c|c|c|c|c|c|}
\hline \multirow[t]{2}{*}{ Treatment } & \multicolumn{3}{|c|}{ No. of tillers plant ${ }^{-1}$} & \multicolumn{3}{|c|}{ Scape length $(\mathrm{cm})$} & \multicolumn{3}{|c|}{ Scape diameter $(\mathrm{cm})$} & \multicolumn{3}{|c|}{$\%$ lodged scapes } \\
\hline & $Y_{1}$ & $\mathrm{Y}_{2}$ & Pooled & $Y_{1}$ & $\mathrm{Y}_{2}$ & Pooled & $Y_{1}$ & $\mathrm{Y}_{2}$ & Pooled & $Y_{1}$ & $Y_{2}$ & Pooled \\
\hline 1 & 4.37 & 4.63 & 4.50 & $46.21 b^{\wedge}$ & $43.33^{\mathrm{de}}$ & $44.77^{b}$ & $1.28^{\mathrm{de}}$ & $1.18^{\mathrm{ef}}$ & $1.23^{\mathrm{ef}}$ & $17.73^{\text {cde }}$ & $11.17^{b}$ & $14.45^{d}$ \\
\hline 2 & 4.13 & 4.53 & 4.33 & $44.55^{b c}$ & $44.47^{\text {cde }}$ & $44.51^{b c}$ & $1.39^{\mathrm{bcd}}$ & $1.26^{\text {def }}$ & $1.33^{\mathrm{d}}$ & $12.94^{f}$ & $22.06^{\mathrm{a}}$ & $17.50^{\text {cd }}$ \\
\hline 3 & 4.97 & 4.20 & 4.58 & $39.83^{\text {de }}$ & $44.13^{\text {cde }}$ & $41.98^{d}$ & $1.39^{\mathrm{bcd}}$ & $1.32^{\text {cde }}$ & $1.35^{c d}$ & $17.12^{\mathrm{de}}$ & $24.84^{\mathrm{a}}$ & $20.98^{\mathrm{abc}}$ \\
\hline 4 & 4.50 & 4.50 & 4.50 & $36.13^{f}$ & $36.33^{g}$ & $36.23^{e}$ & $1.38^{\mathrm{bcd}}$ & $1.56^{\mathrm{a}}$ & $1.47^{\mathrm{ab}}$ & $19.34^{\text {cd }}$ & $17.63^{\mathrm{ab}}$ & $18.48^{\mathrm{bcd}}$ \\
\hline 5 & 3.83 & 4.17 & 4.00 & $35.81^{f}$ & $37.80^{\mathrm{fg}}$ & $36.81^{e}$ & $1.44^{\mathrm{bc}}$ & $1.50^{\mathrm{ab}}$ & $1.47^{\mathrm{ab}}$ & $20.47^{b c}$ & $25.11^{\mathrm{a}}$ & $22.79^{\mathrm{ab}}$ \\
\hline 6 & 4.40 & 4.23 & 4.32 & $32.30^{\mathrm{g}}$ & $42.13^{\mathrm{e}}$ & $37.22^{\mathrm{e}}$ & $1.46^{\mathrm{bc}}$ & $1.28^{\mathrm{def}}$ & $1.37^{c d}$ & $24.35^{\mathrm{a}}$ & $21.17^{a b}$ & $22.76^{\mathrm{ab}}$ \\
\hline 7 & 4.10 & 4.03 & 4.07 & $45.03^{b c}$ & $48.73^{\mathrm{ab}}$ & $46.88^{b}$ & $1.50^{\mathrm{ab}}$ & $1.35^{\mathrm{cd}}$ & $1.43^{\mathrm{bc}}$ & $17.10^{\mathrm{de}}$ & $17.61^{\mathrm{ab}}$ & $17.35^{c d}$ \\
\hline 8 & 4.53 & 4.07 & 4.30 & $42.51^{c d}$ & $50.80^{a}$ & $46.66^{b}$ & $1.28^{d}$ & $1.39^{\mathrm{bcd}}$ & $1.33^{\mathrm{cd}}$ & $15.89^{e f}$ & $27.07^{a}$ & $21.48^{\mathrm{abc}}$ \\
\hline 9 & 4.10 & 4.30 & 4.20 & $43.06^{b c}$ & $48.13^{\mathrm{abc}}$ & $45.60^{\mathrm{b}}$ & $1.35^{\mathrm{cd}}$ & $1.29^{\mathrm{def}}$ & $1.32^{\mathrm{d}}$ & $18.46^{\text {cde }}$ & $18.63^{\mathrm{ab}}$ & $18.55^{\text {bcd }}$ \\
\hline 10 & 3.93 & 4.23 & 4.08 & $37.93^{\mathrm{ef}}$ & $46.27^{\mathrm{bcd}}$ & $42.10^{c d}$ & $1.42^{\mathrm{bc}}$ & $1.20^{\mathrm{ef}}$ & $1.31^{\mathrm{de}}$ & $17.81^{\text {cde }}$ & $17.09^{\mathrm{ab}}$ & $17.45^{c d}$ \\
\hline 11 & 5.27 & 4.27 & 4.77 & $36.85^{\mathrm{ef}}$ & $46.73^{\mathrm{bcd}}$ & $41.79^{d}$ & $1.42^{\mathrm{bc}}$ & $1.35^{\mathrm{cd}}$ & $1.38^{\mathrm{bcd}}$ & $20.05^{\mathrm{bcd}}$ & $20.85^{a b}$ & $20.45^{a b c}$ \\
\hline 12 & 3.70 & 5.70 & 4.70 & $30.70^{\mathrm{g}}$ & $41.33^{\text {ef }}$ & $36.02^{\mathrm{e}}$ & $1.62^{\mathrm{a}}$ & $1.44^{\mathrm{abc}}$ & $1.53^{\mathrm{a}}$ & $22.43^{\mathrm{ab}}$ & $24.07^{a}$ & $23.25^{\mathrm{ab}}$ \\
\hline 13 & 4.33 & 4.17 & 4.25 & $51.11^{\mathrm{a}}$ & $51.07^{a}$ & $51.09^{a}$ & $1.15^{\mathrm{e}}$ & $1.17^{f}$ & $1.16^{f}$ & $25.40^{\mathrm{a}}$ & $24.88^{a}$ & $25.14^{\mathrm{a}}$ \\
\hline $\operatorname{LSD}(p \leq 0.05)$ & NS & NS & NS & $3.19^{* *}$ & $4.04^{* *}$ & $2.50^{* *}$ & $0.13^{* *}$ & $0.14^{* *}$ & $0.09^{* *}$ & $3.0704^{*}$ & $10.149^{* *}$ & $5.16^{* *}$ \\
\hline
\end{tabular}

Table 2: Continue...

\begin{tabular}{|c|c|c|c|c|c|c|}
\hline \multirow[t]{2}{*}{ Treatment } & \multicolumn{3}{|c|}{ Umbel diameter $(\mathrm{cm})$} & \multicolumn{3}{|c|}{ Seed yield (g plant ${ }^{-1}$ ) } \\
\hline & $Y_{1}$ & $Y_{2}$ & Pooled & $Y_{1}$ & $\mathrm{Y}_{2}$ & Pooled \\
\hline 1 & 6.84 & $4.54^{f}$ & $5.69^{c}$ & $3.17^{\mathrm{a}}$ & $3.97^{\mathrm{a}}$ & $3.58^{\mathrm{a}}$ \\
\hline 2 & 6.55 & $5.27^{d}$ & $5.91^{\mathrm{c}}$ & $3.15^{\mathrm{a}}$ & $4.07^{\mathrm{a}}$ & $3.61^{\mathrm{a}}$ \\
\hline 3 & 6.70 & $4.98^{\mathrm{e}}$ & $5.83^{\mathrm{c}}$ & $2.62^{\mathrm{abc}}$ & $2.80^{\mathrm{abc}}$ & $2.72^{\mathrm{bc}}$ \\
\hline 4 & 6.65 & $6.32^{\mathrm{a}}$ & $6.49^{a}$ & $2.03^{c d}$ & $2.00^{c}$ & $2.01^{\text {cde }}$ \\
\hline 5 & 6.83 & $5.80^{\circ}$ & $6.32^{\mathrm{ab}}$ & $2.21^{\mathrm{bcd}}$ & $2.30^{\mathrm{bc}}$ & $2.24^{\text {bcde }}$ \\
\hline 6 & 6.15 & $5.85^{\mathrm{c}}$ & $6.00^{\mathrm{bc}}$ & $1.33^{\mathrm{d}}$ & $2.30^{\mathrm{bc}}$ & $1.81^{\mathrm{de}}$ \\
\hline 7 & 6.60 & $5.83^{\mathrm{c}}$ & $6.21^{\mathrm{b}}$ & $3.05^{\mathrm{ab}}$ & $2.83^{\mathrm{abc}}$ & $2.95^{\mathrm{ab}}$ \\
\hline 8 & 6.54 & $5.77^{c}$ & $6.15^{b}$ & $1.99^{\mathrm{cd}}$ & $3.03^{\mathrm{abc}}$ & $2.51^{\mathrm{bcd}}$ \\
\hline 9 & 6.49 & $5.18^{d}$ & $5.83^{\mathrm{c}}$ & $3.23^{\mathrm{a}}$ & $3.83^{\mathrm{a}}$ & $3.52^{\mathrm{a}}$ \\
\hline 10 & 6.95 & $6.36^{\mathrm{a}}$ & $6.65^{a}$ & $2.60^{\mathrm{abc}}$ & $3.47^{a b}$ & $3.02^{\mathrm{ab}}$ \\
\hline 11 & 6.95 & $5.76^{c}$ & $6.36^{\mathrm{ab}}$ & $1.74^{\mathrm{cd}}$ & $2.47^{\mathrm{bc}}$ & $2.11^{\text {cde }}$ \\
\hline 12 & 6.83 & $6.11^{\mathrm{b}}$ & $6.47^{\mathrm{a}}$ & $1.35^{d}$ & $1.80^{c}$ & $1.57^{\mathrm{e}}$ \\
\hline 13 & 6.76 & $6.08^{b}$ & $6.42^{\mathrm{ab}}$ & $1.57^{\mathrm{d}}$ & $2.23^{\mathrm{bc}}$ & $1.91^{\mathrm{de}}$ \\
\hline $\operatorname{LSD}(p \leq 0.05)$ & NS & $0.15^{* *}$ & $0.33^{* *}$ & $0.93^{* *}$ & $1.29^{* *}$ & $0.781^{* *}$ \\
\hline
\end{tabular}

$\wedge$ Values with same letters in a column are not statistically significant. $Y_{1}$ : year one, $\mathrm{Y}_{2}$ : year two

ethephon at $45 \mathrm{DAP}), \mathrm{T}_{6}(1000 \mathrm{ppm}$ ethephon at $45 \mathrm{DAP})$ and $\mathrm{T}_{9}$ (400 ppm ethephon at 45 and 60 DAP). In comparison control ethephon application did not significant increase the umbel diameter in fact in most of treatments the umbel diameter reduced. Ethephon is a growth retardant phytohormone ( $\mathrm{Li}$ et al., 2013). Like the decrease in scape length, there was also a reduction in umbel diameter. The decrease in the number of florets in flowering annuals- Echinacea, Leucanthemum,
Monarda, and Physostegia due to ethephon application has been reported previously (Hayashi et al., 2001).

\subsection{Seed yield}

Lodging is one of the major issue faced by onion seed growers (Yalamalle et al., 2019). Lodging causes considerable yield and quality losses in onion seed crop. Ethephon application reduced the scape length and increased the scape diameter, 
which provides mechanical strength to the developing scapes. Although there was a reduction in the umbel diameter, lower lodging resulted in higher yield realization. Highest seed yield plant ${ }^{-1}$ (3.61 g) was recorded in treatment $T_{2}(200$ ppm ethephon at 45 DAP) which was also at par with treatments $T_{1}$ (100 ppm ethephon applied at 45 DAP), $T_{7}$ (100 ppm ethephon at 45 and 60 DAP), $T_{9}$ (400 ppm ethephon at 45 and 60 DAP) and $T_{10}\left(600 \mathrm{ppm}\right.$ ethephon at 45 and 60 DAP). Treatment $T_{2}$ (200 ppm ethephon at 45 DAP) also recorded lowest percent lodging (Table 2). The results are in agreement with previous studies by Darginavičienè et al. (2011).

\subsection{Seed germination and vigour}

Lodging is negatively correlated with seed yield and quality (Khan et al., 2018). Application of ethephon significantly $(p \leq 0.05)$ enhanced the seed quality (Table 3$)$. Among the treatment, $\mathrm{T}_{10}$ ( $600 \mathrm{ppm}$ ethephon applied at 45 and $60 \mathrm{DAP}$ ) recorded the highest germination \% (93\%), which was also at par with treatments $T_{4}(600 \mathrm{ppm}$ ethephon at 45 DAP) and $T_{8}$ (200 ppm ethephon at 45 and 60 DAP). Ethephon significantly ( $p \leq 0.01$ ) enhanced the seedling dry weight and highest seedling dry weight was recorded in treatment $T_{1}(100$ ppm ethephon at 45 DAP) (2.32 mg seedling $^{-1}$ ), which was also at par with treatments $\mathrm{T}_{2}$ (200 ppm ethephon at $\left.45 \mathrm{DAP}\right), \mathrm{T}_{3}$ (400 ppm ethephon at $45 \mathrm{DAP}), \mathrm{T}_{4}$ (600 ppm ethephon at 45 DAP), $T_{7}$ (100 ppm ethephon at 45 and 60 DAP), $T_{10}(600$ ppm ethephon at 45 and 60 DAP) and $T_{11}(800$ ppm ethephon at 45 and 60 DAP). The vigour index significantly $(p \leq 0.01)$ enhanced with the application of ethephon and highest vigour index (200.37) was recorded in treatment $T_{10}(600$ ppm ethephon at 45 and 60 DAP), which was also at par with treatments $T_{1}(100$ ppm ethephon at 45 DAP) $\mathrm{T}_{2}$ (200 ppm ethephon at 45 DAP), $\mathrm{T}_{3}$ (400 ppm ethephon at $45 \mathrm{DAP}$ ), $\mathrm{T}_{4}$ (600 ppm ethephon at 45 DAP) and $T_{11}$ (800 ppm ethephon at 45 and 60 DAP). The lodged scapes come in contact with the soil and water, which reduces the seed quality. The enhancement of the seed quality may be due to reduced lodging.

\begin{tabular}{|c|c|c|c|c|c|c|c|c|c|}
\hline \multirow[t]{2}{*}{ Treatment } & \multicolumn{3}{|c|}{ Germination (\%) } & \multicolumn{3}{|c|}{ Dry weight (mg seedling ${ }^{-1}$ ) } & \multicolumn{3}{|c|}{ Vigour index } \\
\hline & $Y_{1}$ & $\mathrm{Y}_{2}$ & Pooled & $Y_{1}$ & $\mathrm{Y}_{2}$ & Pooled & $Y_{1}$ & $\mathrm{Y}_{2}$ & Pooled \\
\hline 1 & $79.33^{\mathrm{bcd}}$ & $80.67^{\text {bcd }}$ & $80.00^{\text {bcde }}$ & $2.03^{\mathrm{abc}}$ & $2.60^{\mathrm{a}}$ & $2.32^{\mathrm{a}}$ & $160.10^{\mathrm{abc}}$ & $210.47^{\mathrm{abc}}$ & $185.28^{\mathrm{abc}}$ \\
\hline 2 & $85.33^{a b c}$ & $82.67^{\mathrm{abcd}}$ & $84.00^{\mathrm{bcd}}$ & $2.00^{\mathrm{abc}}$ & $2.40^{\mathrm{ab}}$ & $2.20^{\mathrm{abc}}$ & $170.47^{\mathrm{ab}}$ & $197.00^{\mathrm{bcd}}$ & $183.73^{\mathrm{abc}}$ \\
\hline 3 & $76.67^{\mathrm{bcd}}$ & $86.67^{\mathrm{abc}}$ & $81.67^{\text {bcde }}$ & $1.77^{\mathrm{bcd}}$ & $2.60^{\mathrm{a}}$ & $2.18^{\mathrm{abc}}$ & $134.67^{\mathrm{bcd}}$ & $226.33^{\mathrm{ab}}$ & $180.50^{\mathrm{abc}}$ \\
\hline 4 & $87.33^{\mathrm{ab}}$ & $87.33^{\mathrm{abc}}$ & $87.33^{\mathrm{ab}}$ & $2.17^{\mathrm{a}}$ & $2.10^{c}$ & $2.13^{\mathrm{abc}}$ & $188.23^{\mathrm{a}}$ & $181.67^{\text {cde }}$ & $184.95^{\text {abc }}$ \\
\hline 5 & $77.33^{\mathrm{bcd}}$ & $79.33^{d c}$ & $78.33^{\text {cde }}$ & $1.97^{\mathrm{abc}}$ & $1.73^{\mathrm{d}}$ & $1.85^{\mathrm{ed}}$ & $152.17^{\mathrm{abc}}$ & $137.00^{f}$ & $144.58^{\text {ed }}$ \\
\hline 6 & $74.00^{\text {cd }}$ & $82.67^{\mathrm{abcd}}$ & $78.33^{\text {cde }}$ & $1.70^{\mathrm{dc}}$ & $2.07^{c}$ & $1.88^{\mathrm{ed}}$ & $125.30^{\text {cd }}$ & $169.57^{\mathrm{ed}}$ & $147.43^{\text {ed }}$ \\
\hline 7 & $76.67^{\mathrm{bcd}}$ & $82.67^{\mathrm{abcd}}$ & $79.67^{\text {bcde }}$ & $2.07^{\mathrm{ab}}$ & $2.30^{\mathrm{bc}}$ & $2.18^{\mathrm{abc}}$ & $158.90^{\mathrm{abc}}$ & $190.57^{c d}$ & $174.73^{b c}$ \\
\hline 8 & $82.67^{\mathrm{abcd}}$ & $88.67^{a b c}$ & $85.67^{\mathrm{abc}}$ & $1.90^{\mathrm{abc}}$ & $2.13^{c}$ & $2.02^{\mathrm{dc}}$ & $156.20^{\mathrm{abc}}$ & $187.47^{c d}$ & $171.83^{b c}$ \\
\hline 9 & $81.00^{\mathrm{bcd}}$ & $83.33^{\mathrm{abcd}}$ & $82.17^{\mathrm{bcd}}$ & $1.97^{\mathrm{abc}}$ & $2.07^{c}$ & $2.02^{\mathrm{dc}}$ & $157.60^{\mathrm{abc}}$ & $173.80^{\text {ed }}$ & $165.70^{\mathrm{bcd}}$ \\
\hline 10 & $94.67^{a}$ & $91.33^{a}$ & $93.00^{\mathrm{a}}$ & $1.80^{\mathrm{bcd}}$ & $2.53^{\mathrm{ab}}$ & $2.17^{a b c}$ & $170.50^{\mathrm{ab}}$ & $230.23^{a}$ & $200.37^{a}$ \\
\hline 11 & $73.33^{\mathrm{cd}}$ & $90.00^{\mathrm{ab}}$ & $81.67^{\text {bcde }}$ & $2.03^{\mathrm{abc}}$ & $2.53^{\mathrm{ab}}$ & $2.28^{\mathrm{ab}}$ & $148.10^{\mathrm{bc}}$ & $225.90^{\mathrm{ab}}$ & $187.00^{\mathrm{ab}}$ \\
\hline 12 & $72.67^{d}$ & $82.00^{\mathrm{abcd}}$ & $77.33^{\text {ed }}$ & $1.90^{\mathrm{abc}}$ & $2.30^{\mathrm{bc}}$ & $2.10^{\mathrm{bc}}$ & $136.03^{\mathrm{bcd}}$ & $188.30^{\text {cd }}$ & $162.17^{d c}$ \\
\hline 13 & $73.33^{\mathrm{cd}}$ & $74.67^{d}$ & $74.00^{\mathrm{e}}$ & $1.50^{\mathrm{d}}$ & $2.10 c$ & $1.80^{\mathrm{e}}$ & $109.30^{d}$ & $154.97^{\text {ef }}$ & $132.13^{\mathrm{e}}$ \\
\hline$p \leq 0.05$ & $12.21^{*}$ & $10.40^{* *}$ & $7.81^{*}$ & $0.33^{*}$ & $0.25^{* *}$ & $0.20^{* *}$ & $37.42^{* *}$ & $31.18^{* *}$ & $23.73^{* *}$ \\
\hline
\end{tabular}

$\wedge$ Values with same letters in a column are not statistically significant. $Y_{1}$ : year one, $Y_{2}$ : year two

\section{Conclusion}

Ethephon significantly reduced the scape height and increase the scape diameter which resulted in lower scape lodging. The reduced lodging also resulted in higher seed yield and seed quality. Hence spraying of onion seed crop with 100 ppm ethephon at 45 DAP is beneficial for getting higher seed yield and quality.

\section{References}

Abo-Elyousr, K.A.M., Alamri, S.A.M., Hussein, M.M.A., Mohamed, A.H.H., Bahaa Abd El-Fatah, E.S., Mohamed,
H., 2020. Molecular disparities among Botrytis species involved in onion umbel blight disease and its management using Bacillus subtilis PHYS7. Egypt Journal of Biological Pest Control 30(1), 1-12.

Addaheri, A.M.S., Abood, N.M., 2020. Response of oat cultivars to ethephon and boron. Iraqi Journal of Agricultural Sciences 51(1), 259-268.

Ahmad, I., Kamran, M., Guo, Z., Meng, X., Ali, S., Zhang, P., Liu, T., Cai, T., Han, Q., 2020. Effects of uniconazole or ethephon foliar application on culm mechanical strength and lignin metabolism, and their relationship with lodging resistance in winter wheat. Crop and Pasture 
Science 71(1), 12-22.

Anonymous, 2018. Food and agriculture data. Available from http://www.fao.org/faostat/en/. Accessed in November 2020.

Anonymous, 2015. ISTA Rules Full Issue. International Rules for Seed Testing 2015, 1-276.

Ashrafuzzaman, M., Millat, M.N., Razi Ismail, M., Shahidullah, S.M., 2009. Influence of paclobutrazol and bulb sizes on seed yield and yield attributing traits of onion (Allium cepa L.) cv Taherpuri. Archives of Agronomy and Soil Science 55(6), 609-621.

Barker, A., McCall, I., Brian. Whipker, E., 2016. Growth control of 'Imperial Dark Blue' plumbago with ethephon, flurprimidol, and paclobutrazol substrate drenches. HortTechnology 24(6), 493-496.

Darginaviciene, J., Novickiene, L., Gaveliene, V., Jurkoniene, S., Kazlauskiene, D., 2011. Ethephon and aventrol as tools to enhance spring rape productivity. Open Life Science 6, 606-615.

Hayashi, T., Heins, R.D., Cameron, A.C., Carlson, W.H., 2001. Ethephon influences flowering, height, and branching of several herbaceous perennials. Scientia Horticulturae 91(3), 305-324.

Khan, S., Anwar, S., Kuai, J., Noman, A., Shahid, M., Din, M., Ali, A., Zhou, G., 2018. Alteration in yield and oil quality traits of winter rapeseed by lodging at different planting density and nitrogen rates. Scientific Reports 8, 634.

Kumar, S., Tomar, B.S., Arora, A., Saharawat, Y.S., Kumar, A., Sharma, R.K., 2016. Influence of plant growth retardants on growth, seed yield and quality in onion (Allium cepa) cv. Pusa Riddhi. Indian Journal of Agricultural Sciences 86(11), 1413-1417

Li, L.L., Gu, W.R., Li, C.F., Li, W.H., Chen, X.C., Zhang, L.G., Wei, S., 2019. Dual application of ethephon and DCPTA increases maize yield and stalk strength. Agronomy Journal 11(3), 1533-1533

Li, Z., Peng, J., Wen, X., Guo, H., 2013. ETHYLENE-INSENSITIVE3 is a senescence-associated gene that accelerates agedependent leaf senescence by directly repressing mir164 transcription in arabidopsis. Plant Cell 25(9), 3311-3328.

Liu, J., Moore, S., Chen, C., Lindsey, K., 2017. Crosstalk complexities between auxin, cytokinin, and ethylene in arabidopsis root development: From experiments to systems modeling, and back again. Molecular Plant 10(12), 1480-1496.

Mangieri, M.A., Mantese, A.I., Schürmann, A.A., Chimenti, C.A., 2016. Effects of ethephon on anatomical changes in sunflower (Helianthus annuus L.) stems associated with lodging. Crop and Pasture Science 67, 988-999.

Mishra, R.K., Jaiswal, R.K., Kumar, D., Saabale, P.R., Singh, A. 2014. Management of major diseases and insect pests of onion and garlic: A comprehensive review. Journal of Plant Breeding and Crop Science 6(11), 160-170.

Praharaj, S., Singh, D., Guru, S.K., Meena, B.R., 2017. Effect of plant growth regulators on tiller dynamics and yield of sugarcane (Saccharum officinarum L.). International Journal of Bio-resource and Stress Management
8(1), 75-78. DOI: HTTPS://DOI.ORG/10.23910/ IJBSM/2017.8.1.1750a

Saithong, T., Saerue, S., Kalapanulak, S., Sojikul, P., Narangajavana, J., Bhumiratana, S., 2015. Gene coexpression analysis inferring the crosstalk of ethylene and gibberellin in modulating the transcriptional acclimation of cassava root growth in different seasons. PLoS One 10(9):e0137602.

Schwartz, H.F., Mohan, S.K., 2016. Compendium of onion and garlic diseases and pests ( $2^{\text {nd }}$ edition). The American Phytopathological Society.

Shi, J., Drummond, B.J., Habben, J.E., Brugire, N., Weers, B.P., Hakimi, S.M., Lafitte, H.R., Schussler, J.R., Mo, H., Beatty, M., Zastrow-Hayes, G., O’Neill, D., 2019. Ectopic expression of ARGOS8 reveals a role for ethylene in root-lodging resistance in maize. The Plant Journal 97, 378-390.

Shiono, K., Ejiri, M., Shimizu, K., Yamada, S., 2019. Improved waterlogging tolerance of barley (Hordeum vulgare) by pretreatment with ethephon. Plant Production Science 22, 285-295.

Tidemann, B.D., Donovan, J.T.O., Izydorczyk, M., Turkington, T.K., Oatway, L., Beres, B., Mohr, R., May, W.E., Harker, K.N., Johnson, E.N., Gooijer, H.D., Thomas, B.W., 2020. Effects of plant growth regulator applications on malting barley in western Canada. Canadian Journal of Plant Science 100(6), 653-665.

Tripathi, S., Sayre, K., Kaul, J., Narang, R., 2003. Growth and morphology of spring wheat (Triticum aestivum L.) culms and their association with lodging: effects of genotypes, $\mathrm{N}$ levels and ethephon. Field Crops Research 84(3), 271-290.

Van de Poel, B., Smet, D., Van Der Straeten, D., 2015. Ethylene and hormonal cross talk in vegetative growth and development. Plant Physiology 169, 61-72.

Wang, Y., Zhao, J., Lu, W., Deng, D., 2017. Gibberellin in plant height control: old player, new story. Plant Cell Reports 36, 391-398.

Yalamalle, V.R., 2016. Effect of bulb size and number of growing axis on seed yield and quality in onion (Allium cepa L.). International Journal of Bio-resource and Stress Management 7(6), 1409-1412.

Yalamalle, V.R., Tomar, B.S., 2019. Effect of scape regulation on seed yield and quality in onion (Allium cepa). Indian Journal of Agricultural Sciences 89(1), 56-59.

Yalamalle, V.R., Tomar, B.S., Kumar, A., Ahammed, S.T.P., 2019. Polymer coating for higher pesticide use efficiency, seed yield and quality in onion (Allium cepa). Indian Journal of Agricultural Sciences 89, 1195-1204.

Zhang, Y., Wang, Y., Ye, D., Wang, W., Qiu, X., Duan, L., Li, Z., Zhang, M., 2019. Ethephon improved stalk strength of maize (Zea mays L.) mainly through altering internode morphological traits to modulate mechanical properties under field conditions. Agronomy 9, 186.

Zhang, N., Han, L., Xu, L., Zhang, X., 2018. Ethephon seed treatment impacts on drought tolerance of kentucky bluegrass seedlings. HortTechnology 28(3), 319-326. 